\title{
Advances in environmental biotechnology and engineering 2018
}

\section{Pablo Gortares-Maroyoqui ${ }^{1}$ - Ruth Gabriela Ulloa-Mercado ${ }^{1}$ Nidia Josefina Ríos-Vázquez ${ }^{2} \cdot$ Luz Breton-Deval $^{3}$. Hervé Macarie ${ }^{4} \cdot$ Hector Mario Poggi-Varaldo ${ }^{5} \cdot$ Isabel Sastre-Conde ${ }^{6}$}

Published online: 11 July 2020

(C) Springer-Verlag GmbH Germany, part of Springer Nature 2020

The sixth ISEBE belongs to a series of symposia (ISEBEs) and meetings (IMEBEs) that arose in Mexico between Mexican researchers and groups of non-Mexican scientists, from Europe, the USA, Brazil, etc., which met every 2 years, with the purpose of presenting the advances of their research works on environmental issues, where, in some way, biotechnology and engineering play an important role. The works of the greatest scientific interest resulting from the different meetings and symposia were published in special issues of scientific journals focused on the management and protection of the environment. These special issues, as well as the books of full articles and the abstract books of the meetings and symposia, can be found at the publications link of ABIAER (http://abiaer.com), the association on Environmental Biotechnology and Engineering, and Renewable Energies created from the first three meetings, IMEBEs.

ABIAER arises essentially to promote scientific exchange between students, scientists, and professionals who interact with the use of tools such as biotechnology and engineering, as well as the search for renewable energies to achieve a more sustainable environment. Likewise, the ABIAER supports

Responsible Editor: Philippe Garrigues

Isabel Sastre-Conde

isabelsastre2003@yahoo.es; misastre@semilla-caib.es

Pablo Gortares-Maroyoqui

Pablo.gortares@itson.edu.mx

Ruth Gabriela Ulloa-Mercado

ruth.ulloa@itson.edu.mx

Nidia Josefina Ríos-Vázquez

nidia.rios@itson.edu.mx

Luz Breton-Deval

lzbreton@ibt.unam.mx

1 Departamento de Biotecnología y Ciencias Alimentarias, Instituto Tecnológico de Sonora, 5 de Febrero 818 Sur, CP, 8500 Ciudad Obregón, Sonora, Mexico and promotes the symposia on bioengineering and environmental engineering (ISEBEs) in order to allow access to information on the topics highlighted in the works published throughout the IMEBEs/ISEBEs history. In these publications, you can get papers about research on environmental impacts on natural ecosystems. Impacts characterized by pollution, degradation, and definitely loss of natural resources. In addition, it is possible to examine the advances in technological and engineering processes about treatment of wastewater (Macarie et al. 2018), gaseous effluents, and contaminated soils, but also advances in the characterization of both the microbiota of natural ecosystems and microbial biomass of biotechnological processes using molecular biology and genomic techniques (Vargas et al. 2017).

The contents of the IMEBEs/ISEBEs found in ABIAER show a trajectory of the evolution of research topics according to the course of environmental events, social progress measured in technological improvements, in parallel to scientific resolution in response to problems involving the environment and society. Thus, these contents published in special issues have first started by a state of the art of the environmental

2 Departamento de Ciencias del Agua y Medio Ambiente, Instituto Tecnológico de Sonora, 5 de Febrero 818 Sur, CP, 8500 Ciudad Obregón, Sonora, Mexico

3 CATEDRAS-CONACYT, Instituto de Biotecnología, Universidad Nacional Autónoma de México, Avenida Universidad 2001, Colonia Chamilpa, 62210 Cuernavaca, Morelos, Mexico

4 IRD, Aix Marseille Univ, Avignon Université, CNRS, IMBE, Marseille, France

5 Environmental Biotechnology and Renewable Energies R\&D, Group, Dept. Biotechnology and Bioengineering, Cinvestav-IPN, Av. Instituto Politécnico Nacional 2508, Col. San Pedro Zacatenco, Delegación Gustavo A. Madero, C. P. 07360, 14-740, 07000 Mexico City, Mexico

6 SEMILLA-INAGEA, Calle Babieca no. 2, 07198 Son Ferriol, Balearic Islands, Palma, Spain 
problems, which considers the effects of pollution from industries, transport, agriculture, etc., on natural resources, water, atmosphere, and soil, since these resources are limited and therefore vulnerable to over-exploitation. From the impact study, the search for environmental management strategies and decontamination (Camacho-Pérez et al. 2012) and restoration (Pastor and Hernández 2012) tools that go from sustainable development through the recovery of waste (MartínezGarcía et al. 2012) to life cycle analysis and environmental recommendation can be found in the special issue of 3IMEBE (Sastre-Conde et al. 2012).

Pollution caused by direct or collateral effects of man on the environment has different origins and can be seen in different gradients of extension and collateral influence to other media. The effects of pollution on the environment cause degradation in natural ecosystems, which after time and awareness of governments and the population forces to take a responsible and sustainable knowledge of industrial processes and the global economy. In the same way, this knowledge must be shared between technology and science to jointly make decisions to minimize environmental impact and analyze existing tools for the recovery of natural systems through bio-restoration, phyto-restoration technologies (GarcíaGonzalo et al. 2017), biosorption, electrokinetic techniques and restoration engineering, etc.

The historical evolution of pollution dates back to a long period of uncontrolled operation of industry, agriculture, animal breeding, transport, etc., with effects such as air and water pollution. Added to this is the contamination of water and soil by health and human care products (Devault et al. 2017). Likewise, the progressive contamination due to the agricultural revolution that has allowed the increase of crop yields through the use of chemical fertilizers, pesticides, etc., but has resulted in the accumulation of heavy metals in soils, as well as synthetic chemical compounds. We are facing a contamination that affects the global level, without respecting borders, and that can reach considerable extensions, as occurs in the case of plastics in the sea, or the increase in $\mathrm{CO}_{2}$ levels in the atmosphere, a contamination which not only results from the industrial activity but also from the agriculture itself (López-López et al. 2012). The uses of fossil energy sources, in addition to having a life limit, are themselves a source of pollution and global climate change. An unsustainable economic system, with a depletion of the fossil energy sources, an increase in the production of waste and therefore with a higher level of contamination of resources, promotes societies with noncircular economies with a degradation and deterioration of the environment. This is reflected at a scientific level in the special issue of 4ISEBE (Poggi-Varaldo et al. 2017), in the search for new energies from the use of organic waste (Escamilla-Alvarado et al. 2017).
In recent years, there has been significant concern about the accumulation of recalcitrant and toxic organic compounds in soils and groundwater resulting from, either point contamination decades ago, or cumulative contamination over time. These pollutants can be responsible of serious human and animal health problems, since they can pass from water and soil to the food chain. Likewise, according to the concern of human health, regulations arise to limit collateral contamination by intensive production farms for animals (pigs, chickens, etc.), studying processes for improving the treatment of their wastewater (Córdoba et al. 2018). These regulations restrict the prevalence of biological contaminants for the reuse of these wastes in agricultural soils, for example, pathogenic microorganisms in organic waste such as food waste, manure, slurry, and for this, treatment techniques are sought (e.g., for manure, Venglovsky et al. 2018). The same occurs with the elevation of nitrates in waters that are sources of disease. Thus, we are in the special issue of 5ISEBE (Candal et al. 2018), with a follow-up of the decontamination of recalcitrant organic compounds and the increasing emergence of the use of pesticides that are more sustainable, ecological, and cleaner and so more respectful of the environment (Candal et al. 2018).

The special issue in hand groups a selection of the works presented during 6ISEBE (see abstract book, Rios-Vazquez et al. 2019). Several of them are focused on the evaluation of pollutants of different origins in man and animals, but there is also an interest in the use of organic waste as an energy source. Likewise, as in previous IMEBEs/ISEBEs, attention is focused on the power of microorganisms in order to help mitigate environmental pollution. In this special issue, we are at the moment of recognition of the presence of emerging pollutants in the environment. These pollutants are especially sought in wastewater. In addition, the possibility of using wastewater to extract and obtain "high added value chemical compounds" is sought. This issue also includes works with a more ecological vision of dual health, human, and environmental, as a one health. Therefore, in this issue, we are balancing cleaner and more sustainable production together with the reuse of compounds and energy, from organic waste and wastewater. The reuse of compounds and energy goes towards a circular economy. This type of economy would link with the objective of the ISEBEs, to bring together advances in engineering and biotechnology for environmental health, which, analyzed in the environment, would be to work from it to favor and improve it.

Finally, it must be pointed out that along their history, the IMEBEs and ISEBEs, focused on environmental areas, sometimes more regional than global, such as the latter ISEBE, which focused on realities centered in areas of North America, Central America, and South America, which marks a particular reality in terms of pollutants related to different legislation and economies. 
The works enclosed in the present special issue encompass the following topics.

I. Organic waste and energy

II. Wastewater and pollutants

i. Inorganic contaminants

ii. Emerging contaminants such as medicines

iii. Production of esterified fatty acids as fuels

III. Evaluation of pollutants from different origins (agriculture, drugs, etc.) in

i. Men

ii. Animals

IV. Microorganisms and mitigation of environmental deterioration

i. Degradation of organic pollutants (pesticides) by bacteria

ii. $\mathrm{CO}_{2}$ bio mitigation

V. Plants and human health. Natural biopharmaceuticals.

ABIAER will continue working to publicize the advances in research in the field of biotechnology and environmental engineering, as well as the advances in research that seek more environmentally sustainable energy production methods, allowing an economic environment that is healthier to the planet. This knowledge will be disseminated through consultancies, courses, colloquia, seminars, symposiums, etc., to which students, scientists and professionals are invited to participate, because together and by joining efforts, it is possible to create an environment compatible with the life of all living beings. Among this dissemination of knowledge, ABIAER invites you to participate to the next editions of the ISEBEs that will continue to make an effort so that, on an international basis, more and more people want to be part of this family of researchers who will meet in periods ranging from 2-3 years to present, discuss, and value their research, and enhance particularly the research of young students.

\section{References}

Camacho-Pérez B, Ríos-Leal E, Rinderknecht-Seijas N, Poggi-Varaldo HM (2012) Enzymes involved in the biodegradation of hexachlorocyclohexane: a mini review. J Environ Manag 95:S306-S318

Candal R, Curutchet G, Dominguez-Montero L, Macarie H, PoggiVaraldo HM, Sastre-Conde I, Vasquez SC (eds) (2018) Environmental Science and Pollution Research 25(22), special issue "Advances in environmental biotechnology and engineering 2016", pp 21267-21466. https://link.springer.com/journal/11356/25/22
Córdoba V, Fernández M, Santalla E (2018) The effect of substrate/ inoculum ratio on the kinetics of methane production in swine wastewater anaerobic digestion. Environ Sci Pollut Res 25(22): 21308-21317

Devault DA, Néfau T, Levi Y, Karolak S (2017) The removal of illicit drugs and morphine in two waste water treatment plants (WWTPs) under tropical conditions. Environ Sci Pollut Res 24(33):2564525655

Escamilla-Alvarado C, Poggi-Varaldo HM, Ponce-Noyola MT (2017) Bioenergy and bioproducts from municipal organic waste as alternative to landfilling: a comparative life cycle assessment with prospective application to Mexico. Environ Sci Pollut Res 24(33): 25602-25617

García-Gonzalo P, del Real AP, Lobo MC, Pérez-Sanz A (2017) Different genotypes of Silene vulgaris (Moench) Garcke grown on chromium-contaminated soils influence root organic acid composition and rhizosphere bacterial communities. Environ Sci Pollut Res 24(33):25713-25724

López-López G, Lobo MC, Negre A, Colombàs M, Rovira JM, Martorell A, Sastre-Conde I (2012) Impact of fertilisation practices on soil respiration, as measured by the metabolic index of short-term nitrogen input behaviour. J Environ Manag 113:517-526

Macarie H, Esquivel M, Laguna A, Baron O, El Mamouni R, Guiot SR, Monroy O (2018) Strategy to identify the causes and to solve a sludge granulation problem in methanogenic reactors: application to a full-scale plant treating cheese wastewater. Environ Sci Pollut Res 25(22):21318-21331

Martínez-García C, Eliche-Quesada D, Pérez-Villarejo L, IglesiasGodino FJ, Corpas-Iglesias FA (2012) Sludge valorization from wastewater treatment plant to its application on the ceramic industry. J Environ Manag 95:S343-S348

Pastor J, Hernández AJ (2012) Heavy metals, salts and organic residues in old solid urban waste landfills and surface waters in their discharge areas: Determinants for restoring their impact. J Environ Manag 95: S42-S49

Poggi-Varaldo HM, Devault D, Macarie H, Sastre-Conde MI (eds) (2017) Environmental Science and Pollution Research 24(33), special issue "4th International Symposium on Environmental Biotechnology and Engineering-2014”. pp 25483-25774 https:// link.springer.com/journal/11356/24/33

Rios-Vazquez NJ, Ulloa-Mercado RG, Sanchez-Duarte RG, CorreaMurrieta MA, Gortárez-Moroyoqui P (2019) Book of abstracts, environmental biotechnology and engineering - 2018. ITSON, Ciudad Obregón, Sonora, Mexico, pp 1-264 https://www.itson.mx/eventos/ 6isebe/SiteAssets/Paginas/documents/ABSTRACTS-BOOK6ISEBE-2019.pdf

Sastre-Conde I, Poggi-Varaldo MH, Lobo MC, Sanz JL, Macarie H (eds) (2012) Journal of Environmental Management 95 (supplement), "Environmental risk and problems, strategies to reduce them through biotechnology and engineering", pp S1-S368. http:// horizon.documentation.ird.fr/exl-doc/pleins_textes/divers16-03/ 010054771.pdf

Vargas JP, Carmona SEV, Moreno EZ, Casado NAR, Calva GC (2017) Bioremediation of soils from oil spill impacted sites using bioaugmentation with biosurfactants producing, native, free-living nitrogen fixing bacteria. Revista Internacional de Contaminación Ambiental 33:105-114

Venglovsky J, Sasakova N, Gregova G, Papajova I, Toth F, Szaboova T (2018) Devitalisation of pathogens in stored pig slurry and potential risk related to its application to agricultural soil. Environ Sci Pollut Res 25(22):21412-21419

Publisher's note Springer Nature remains neutral with regard to jurisdictional claims in published maps and institutional affiliations. 


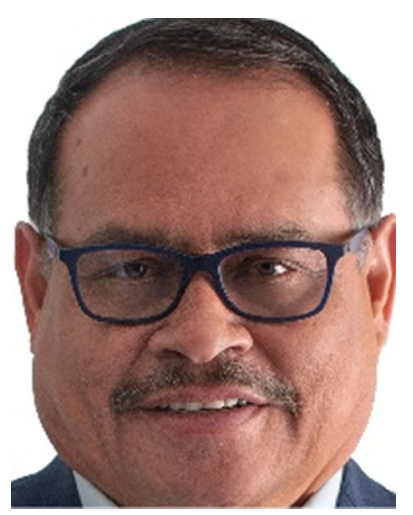

Pablo Gortares-Maroyoqui is a full professor in the Dept. of Biotechnology and Food Sciences at The Technological Institute of Sonora (ITSON for its acronym in Spanish). He holds a B. Sc. in Biochemical Engineering (1984) from Technological Institute of Culiacan, a M. Sc. in Bioengineering (1987) from Center of Research and Advances Studies, National Polytechnic Institute (CINVESTAV, IPN, for its acronym in Spanish) and a Ph. D. in Environmental Sciences from the University of Arizona, USA (2007). He works at ITSON since 1987. He was responsible of Eco-Development Department (1991-1997). He was the Dean of the Natural Resources Division (2003-2009). He was the responsible of Biotechnology Ph. D. program (2010-2019). He was one of the founders of this academic program, as well as of the Natural Resources M. Sc. Both programs are qualified as higher or consolidated level by the Science and Technology National Council (CONACYT, for its acronym in Spanish). He has developed research in environmental sciences, mainly related to water quality, wastewater treatment, wastewater reuse, and impact and risk assessment by the reuse of wastewater, and solid wastes reuse. His research around wastewater treatment focuses on biological, electrochemical, and physicochemical processes even alone or coupled. He has mentored 14 M. Sc., 7 Ph. D. and around 35 B. Sc. thesis. He has published 34 articles in recognized international journals. He has around 150 research works presented in Mexican and international congresses and conferences. He has level I recognition of The National Researcher System (SNI, for its acronym in Spanish) of CONACYT. $\mathrm{He}$ is an active member of the American Society of Microbiology (ASM), the International Water Association (IWA), the American Chemical Society (ACS), the Mexican Society of Biotechnology and Bioengineering (SMBB for its acronym in Spanish) and the Engineering Academy of Mexico (AI for its acronym in Spanish). He was the main organizer of the Sixth International Symposium on Environmental Biotechnology and Engineering (6ISEBE), which took place at ITSON in Ciudad Obregón, México.

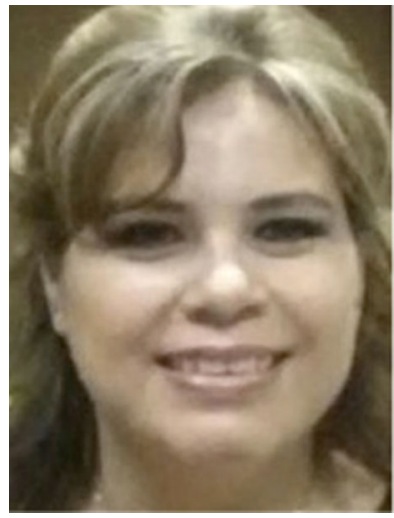

Ruth Gabriela Ulloa-Mercado is a full professor in the Dept. of Biotechnology and Food Sciences at The Technological Institute of Sonora (ITSON for its acronym in Spanish). She hold s a B. S c . i n Biotechnological Engineering (1994), and M. Sc. in Natural Resources (2001), both from Technological Institute of Sonora, and a Ph. D. in Chemical and Environmental Engineering from the University of Santiago de Compostela, Spain (2012). She works at ITSON since 2001. She was responsible of Biotechnological Engineering program (2003-2006). She is the responsible of Biotechnology $\mathrm{Ph}$. D. program (2019 until today); this program is qualified as higher or consolidated level by the Science and Technology
National Council (CONACYT, for its acronym in Spanish). She has developed research in microalgal biotechnology with applications on environmental sciences, mainly related to wastewater treatment to remove macro- and microcontaminants, like antibiotics and hormones in porcine wastewater, in systems combined with photodegradation, applying Aqueous Biphasic Systems (ABS) based on ionic liquids (biodegradable and environmentally friendly) to extract and concentrate the microcontaminant. Also, applications on aquaculture, mainly using microalgal biomass as an additive in shrimp feed to stimulate its growth and immune system. She has mentored $4 \mathrm{M}$. Sc., $3 \mathrm{Ph}$. D. and around 10 B. Sc. theses. She has published 10 articles in recognized international journals. She has around 20 research works presented in Mexican and international congresses and conferences. She has level I recognition of The National Researcher System (SNI, for its acronym in Spanish) of CONACYT. She is an active member of American Society of Microbiology (ASM) and of Mexican Society of Biotechnology and Bioengineering (SMBB, for its acronym in Spanish). She was one of the main organizers of the Sixth International Symposium on Environmental Biotechnology and Engineering (6ISEBE), which took place at ITSON in Ciudad Obregón, México.

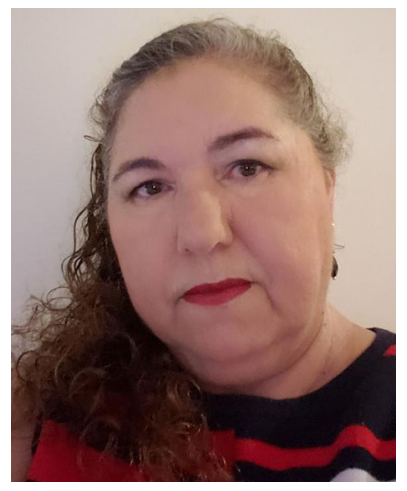

Nidia Josefina Ríos-Vázquez is a full professor in the Dept. of Water and Environmental Sciences at the Technological Institute of Sonora (ITSON for its acronym in Spanish). She is a Chemical Engineer with a master's degree in Engineering in Optimization of Productive Systems and a PhD in Strategic Planning for Performance Improvement. She is currently a professor-researcher, belongs to the national system of researchers in Mexico. She is a professor of undergraduate and postgraduate degrees in the areas of Project Management, Production Planning, and Occupational Safety and Health; she has served as leader of the consolidated academic body of productive chains, has directed the academic management of the Chemical Engineering educational program, and currently heads the Department of Water and Environmental Sciences. She is the author of the books "The Maturity of Performance Measurement Systems in Certified Organizations" and "Decision Making, and Maturity of Organizational Processes in Small Businesses: A Model for Improving Performance," as well as book chapters with recognized publishers. She has published and ruled on articles in various indexed and refereed magazines. She was Member of the scientific committee and organizer of the Sixth International Symposium on Environmental Biotechnology and Engineering (6ISEBE), which took place at ITSON in Ciudad Obregon, Mexico. 


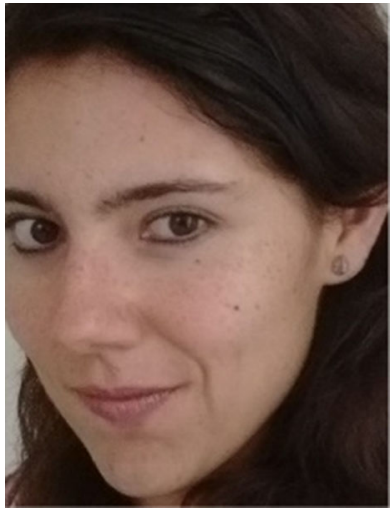

Luz Breton-Deval holds a Chair for outstanding young researchers of the Mexican National Council of Science and Technology (CONACYT for its acronym in Spanish) and she is an assistant professor in The Biotechnology Institute of the National Autonomous University of Mexico (UNAM for its acronym in Spanish). She holds a B. Sc. in Biology (2008) from the Guadalajara University, an M. Sc. and Ph. D in Biotechnology (2011/2015) from the Center of Research and Advanced Studies of the National Polytechnic Institute (CINVESTAV for its acronym in Spanish). She worked with anaerobic bioreactors to remove chlorinated compounds and improved the reactors by coupling filters of iron nanoparticles. After her Ph D., she worked a year in the Department of Chemical Engineering of the University of Guadalajara, working with biogas production (postdoctoral fellow, SENER-CONACYT 2016). In 2017, Breton-Deval, along with other colleges, received the McKee Groundwater Protection, Restoration or Sustainable Use Award by the Water Environment Federation, USA for her contribution to accelerating the cleaning of groundwaters published in "Biodegradability of Nonionic Surfactant Used in the Remediation of Groundwaters Polluted with PCE." Her research interest is focused on bioremediation and the understanding of the microbial ecology of the processes. She believes that the deep understanding of the microbial community could accelerate the removal of pollutants and improve any industrial process. She is an active member and current president of the Association of Biotechnology, Environmental Engineering and Renewable Energies (ABIAER, for its acronym in Spanish) which promotes The Symposiums on Environmental Biotechnology and Engineering (ISEBE) and the research in environmental sciences.

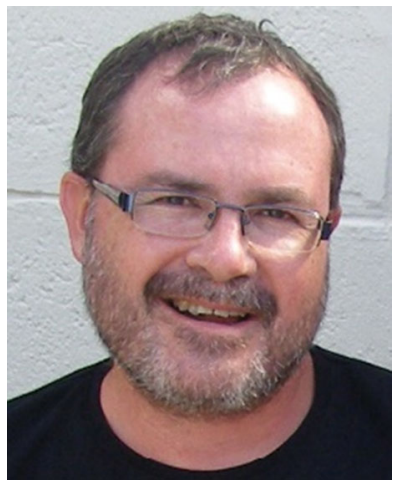

Hervé Macarie is a research officer at the French National Research Institute for Sustainable Development (IRD exORSTOM). In this position since October 1994, he has developed research on the technological and the microbiological aspects (taxonomy \& ecology) of the anaerobic treatment of industrial wastewater and he has both an experience at lab and full scale (up to reactors of $20,000 \mathrm{~m}^{3}$ ). One of his main interests has been for the anaerobic degradation of xenobiotic compounds such as terephthalic acid and pentachlorophenol and the development of synchronous anaerobic/aerobic systems to achieve the full mineralization of this last compound. Since 2008, his research has been almost entirely focused on the microbial degradation of chlordecone, an organochlorine insecticide classified as POP that was once used against the banana black weevils and that is now responsible, 24 years after the ban of its utilization, of a health, environmental, economic and social crisis in the French West Indies islands of Guadeloupe and Martinique. Along his career, he has been successively in position in Canada (postdoctoral fellow, BRI, NRC, 1992-1994), Mexico (visiting professor, UAM-Iztapalapa, 1995-2000), continental France (Aix
Marseille University, 2001-2010), and Martinique (CAEC, 20112014). Since 2015, he is back to Aix Marseille University and IMBE (Mediterranean Institute for Marine and Continental Biodiversity and Ecology) where he pursues his research on the theoretical and experimental aspects of chlordecone degradation with the objective to understand the factors limiting its natural attenuation and the possibility to manipulate them in order to propose a bioremediation process to decontaminate the polluted soils. He has been associated to the IMEBEs/ISEBEs series of event since their creation back in 2004 and he is now a member of the international board of the ABIAER association.

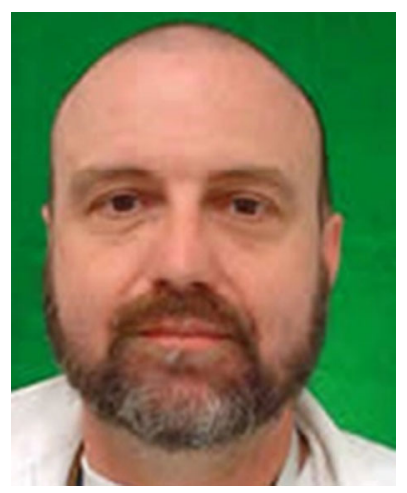

Héctor Mario Poggi Varaldo is a full professor in the Dept. of B i o t e c nolog a $\mathrm{nd}$ Bioengineering at the Center for Higher Studies and Research (CINVESTAV del IPN) in Mexico City, Mexico. He is the founder and leader of the Environmental Biotechnology and Renewable Energies R\&D Group (GBAER for its abbreviation in Spanish). He holds a Sc. D. degree in Biotechnology from CINVESTAV del IPN, a M. Sc. Environ. Eng. from the National Autonomous University of Mexico, and a B. Sc. Chem. Eng. from the National University of Uruguay. He has been awarded the Prize to Distinguished Academic Career from the Mexican Polytechnic Institute in 1999. He has also won two awards to the Best Research Projects from the Mexican Society for the Management of Solid and Hazardous Wastes in 1998. Professor Poggi-Varaldo has received the Award "Professor McKee Award to excellence in groundwater restoration" from the Water Environment Federation (USA) in 2017, several awards from Conferences and Symposia organized by Battelle Memorial Institute (USA), and the Award to Best Poster in the 3rd International Energy Conference 2019 (México). He has been invited as an expert in soil bioremediation by the French government for advising on the chlordecone contamination and remediation in the French West Indies in 2010. Also, the European Commission invited him in 2011 to perform as a referee for evaluation of megaprojects submitted to the 7th EU Research Framework Program. Furthermore, he is the author of a Mexican Patent on a type of anaerobic fluidized bed reactor as well as a patent application for generation of biohydrogen and methane from organic solid wastes. His research interests are focused on (i) bioenergies and biorefinery of organic wastes, (ii) bioremediation of heavy soils polluted with pesticides, (iii) bioelectricity from effluents, (iv) treatment of toxic and industrial wastewaters, and (v) nanobiotechnology applied to bioelectrochemical devices and bioremediation of soils and aquifers. He is the author of nearly 140 articles in refereed journals indexed in the Web of Science (WOS). He holds the category H24 according to the WOS. Also, he has published more than 40 chapters in books and has been the editor of 10 books, as well as more than 150 full articles in international symposia and congresses. Several years ago, Professor Poggi-Varaldo accompanied by a group of recognized international and Mexican academicians and professionals, founded the ABIAER A.C., the Association for Environmental Biotechnology and Engineering and Renewable Energies. This international association seeks to foster and support knowledge generation and academic/professional interaction to achieve the development and application of Environmental Biotechnology and Environmental Engineering tools to improve the quality of environment and quality of life of our societies. A particular, although significant goal 
of this association, it is to contribute to the development and implementation of a new platform of renewable energies that could replace fossil fuel-based energy in the near future.

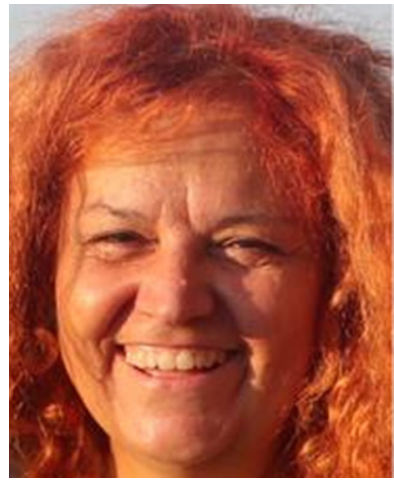

Isabel Sastre-Conde qualified in $\mathrm{BSc}$ in Biological Sciences from the Complutense University of Madrid and doctoral degree in Agricultural Chemistry at the Autonomous University of Madrid. She has participated in the frame of the AECI-ANUIES Spanish-Mexican program of reinforcement of Mexican province Universities as a ResearcherProfessor first at the UNACAR (Universidad Autonoma del Carmen), Campeche State and then at UV (Universidad Veracruzana) in Veracruz City. During that period, she started collaboration with Dr. Poggi's environmental lab at Cinvestav-IPN, Mexico, where she later made three short-term stays while she had a postdoctoral research position at IMIDRA (Instituto Madrileño de Investigación y Desarrollo Rural, Agrario y Alimentario) in Spain. In 2004, she obtained a 5 years researcher position at Conselleria d'Agricultura from Balearic Island (Spain) into the frame of the DOC-INIA program. Since 2006, she got a permanent researcher position at SEMILLA (a semi-public company under the authority of the Agricultural Regional Direction of the Balear Province Government). Currently, she is a permanent researcher of SEMILLA-INAGEA. Her main research interest has been towards the study of the risk of contamination of soils and sediments as well as towards the restoration and remediation of impacted environments. On these aspects, she has participated in numerous projects in collaboration with IMIDRA, within the framework of EIADES program. With researchers from other countries, she was involved in Mexican projects on the impact of the oil industry on coastal lagoon systems, but also on the impact of long-term (100 years) irrigation with raw sewage on agricultural soils. In collaboration with French researchers, she has worked also on the bioremediation of soils contaminated by chlordecone, an organochlorine insecticide used during decades for the control of the populations of banana weevils in French West Indies. Since 2006, her research activity has been focused towards the use of composted organic material as an alternative to the inorganic nitrogen fertilizer presently used in important crops of the Balearic Islands (almonds and tomatoes) with the objective to reduce at minimum the risk of aquifer pollution by nitrate. All these research activities have given her a deep knowledge of the soil characteristics under stress situations (natural, agrarian, degraded, and polluted soils). Very recently, she started to participate to projects on soil bioremediation with nano-materials, the use of soil for a sustainable agriculture and the role of soil on the risk of invasion by the Xylella fastidiosa bacteria for the agriculture of the Balearic Islands. Isabel Sastre has participated in agrarian national and international research projects in relation to the AKIS (Agricultural Knowledge and Innovation Systems). She cooperates with ABIAER as international vice-president whose role is to promote the transfer of environmental knowledge and the preparation of projects between international groups, the dissemination of ISEBE news, the control of rules and the preparation of ISEBEs and conference grants. 